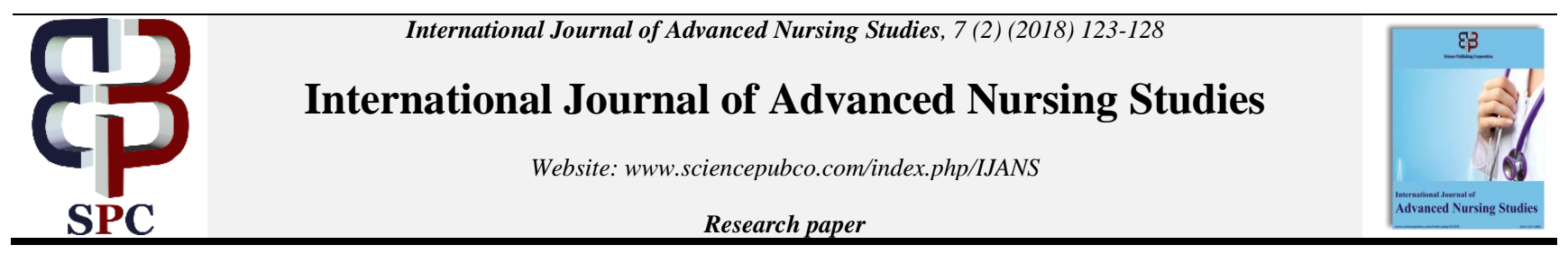

\title{
Effect of nursing teaching program on knowledge and self-management behaviors for patients with essential hypertension
}

\author{
Shymaa Helmy Ahmed Abd Alaleam ${ }^{1 *}$, Zeinab Abd El-Latif Mohammad ${ }^{2}$, \\ Mohammed Hossam El-dien ${ }^{3}$, Sahra Zaki Azer ${ }^{4}$ \\ ${ }^{1}$ Adult of Nursing Dept., Faculty of Nursing, Qena University, Egypt \\ ${ }^{2}$ Medical-Surgical Nursing Dept., Faculty of Nursing, Assist University, Egypt \\ ${ }^{3}$ Medical Dept. , Faculty of Medicine, Assist University, Egypt \\ ${ }^{4}$ Medical-Surgical Nursing Dept. , Faculty of Nursing, Assist University, Egypt \\ *Corresponding author E-mail: shymaahelmy@ymail.com
}

\begin{abstract}
Background: Essential hypertension is the most common cardiovascular disease (CVD), affecting about one billion individuals worldwide. Aim of the study: was to evaluate the effect of nursing teaching program on knowledge and self-management behaviors for patients with essential hypertension. Study design; quasi-experimental research design was utilized to conduct this study.

Setting: The study was conducted in the internal medicine department and outpatient clinics at Assiut University Hospital.

Sample: Sixty adult patients of both sexes divided equally into 2 groups study and control group (thirty for each). Tools; four tools were used for data collection; Patients, assessment sheet, Hypertension Knowledge-Level Scale (HK-LS), Hypertension Self-Management Behavior Questionnaire (HSMBQ)" and Nursing Teaching Program. Results; the majority of the study and control groups were female (83.3\%, $66.7 \%)$, married $(80.0 \%, 86.7 \%)$, illiterate $(66.7 \%, 60.0)$, and house wives $(83.3 \%, 63.3 \%)$.

Conclusion: Nursing teaching program was effective in improving patients' knowledge and self-management behaviors. Recommendations; educational program should be planned and offered to patients on regular basis. Simple booklets should be available for patients to provide them with simple explanation about the disease.
\end{abstract}

Keywords: Essential Hypertension; Nursing Teaching Program.

\section{Introduction}

Cardiovascular disease (CVD) is a group of diseases that involve the heart or blood vessels. CVD includes coronary artery diseases (CAD) such as angina and myocardial infarction (Wikipedia, 2016). CVDs are the number one cause of death globally. About 17.5 million people died from CVDs in 2012, representing $31 \%$ of all global deaths, 7.4 million of these deaths were due to coronary heart disease (CHD) and 6.7 million were due to stroke (World Health Organization, 2016).

Hypertension (HTN) is a very important risk factors contributing to the CVD burden, as it is a significant contributor to CVD related morbidity and mortality (Babu and Grace, 2015). HTN, also known as high blood pressure (BP), affects millions of people. High blood pressure is defined as $\mathrm{BP} \geq 140 / 90$ millimeters of mercury $(\mathrm{mmHg}$ ) (Bell et al., 2015). Hypertension remains one of the most important preventable contributors to disease and death. Abundant evidence from randomized controlled trials (RCTs) has shown benefit of antihypertensive drug treatment in reducing important health outcomes in persons with HTN (James et al., 2014 and Baushi, 2015). Hypertension (HTN) is divided into two main categories: essential (primary; idiopathic) and secondary (O'Sullivan et al., 2014 and Ciccone, 2015). Essential HTN is an elevated blood pressure of undetermined cause (Bolívar, 2013 and Mangena et al., 2016). More than $90 \%$ of all hypertensive persons are reported to have essential hypertension (Ghosh et al., 2013 and Liao et al., 2014).

Secondary hypertension is defined as increased systemic blood pressure (BP) due to an identifiable cause (Rimoldi et al., 2013). It represents 5-10\% of hypertensive cases (Conn, 2013 and Alp et al., 2014).

Essential hypertension is the most common cardiovascular disease (CVD), affecting about one billion individual worldwide (Li et al., 2014). The primary causes of essential hypertension include heredity, environment, habits, and dietary history (Dalai et al., 2014). A patient with severe hypertension may experience a variety of symptoms secondary to the effects on blood vessels in the various organs and tissues or to the increased workload of the heart. These secondary symptoms include fatigue, dizziness, palpitations,

Angina, and dyspnea. In the past, symptoms of hypertension were thought to include headache and nosebleeds (Lewis et al., 2014). Self-management of chronic illness is that people participate effectively in managing their own health care on an ongoing basis. Optimal self management requires that the person understands the illness and manages their care, including taking medications and participating in decision-making with their health providers regarding their illness. Additionally, people must manage the impact of the chronic illness on their daily life, maintain their general health and avoid risk factors for other illnesses, for example, eating a healthy diet and participating in regular exercise (Gallagher et al., 2008). 
HTN self-management behaviors including medication adherence, self-blood pressure monitoring, and lifestyle modifications involving diet, exercise, and tobacco are critical components of recommended hypertension treatment and have been associated with significant improvements in hypertension control (Flynn et al., 2013). Self-management education increases self care knowledge about hypertension, compliance with healthcare appointments and selfcare behaviors, decreased healthcare use and improves adherence to medication and exercise in nursing home residents or community-dwelling older adults with hypertension (Mersal and Mersal, 2015).

\subsection{Aim of the study}

The aim of study was to evaluate the effect of nursing teaching program on knowledge and self-management behaviors for patients with essential hypertension.

\section{Patients and method}

\subsection{Research design}

Quasi-experimental research design was utilized to conduct this study.

\subsection{Setting}

The study was conducted in the internal medicine department and outpatient clinics at Assiut University Hospital.

\subsection{Patients}

60 adult patients, the age between (18-65) years divided equally into 2 groups; study and control groups (thirty for each group) with a medical diagnosis of essential hypertension, both sexes (male and female), oriented, and able to provide oral consent.

\subsection{Tools of the study}

Tool I: Patients' assessment sheet

It was developed and utilized by the researcher based on literature review to assess patients with essential hypertension. This tool consists of the following two parts:-

Part (1): Socio demographic data for the patients as (name, age, sex, level of education, marital status, and employment).

Part (2): Medical data including: vital signs, symptoms of hypertension, family history of HTN, duration of illness, smoking, and obesity or overweight.

Tool II: Hypertension Knowledge-Level Scale (HK-LS) (Pr / Post 6 weeks):

(Erkoc et al., 2012) developed it. This questionnaire sheet was used to measure the exact knowledge of patient's pre and post implementation of the nursing teaching program.

It is a self-report questionnaire consisting of 22 items with sub-dimensions consisting of the definition of hypertension ( 2 items), medical treatment (4 items), drug compliance (4 items), lifestyle (5 items), diet (2 items), and complications (5) items.

Scoring system:

The total score was (22 grades), these scores were converted into a percent score, the results of patient were classified into two categories $(<50 \%)$ was unsatisfactory knowledge, and $(\geq 50)$ was satisfactory level of knowledge.

Tool III: - Hypertension Self-management Behavior Questionnaire (HSMBQ) (Pr / Post 6 weeks):

Akhter, 2010, developed it. It consists of 40 items addressing different aspects of self-management for illness. These include: selfintegration (13 items); self-regulation ( 9 items); interaction with health professionals and significant others ( 9 items); self-monitoring (4 items); and adherence to recommended regimen (5 items). It has five levels for the questions; $1=$ never (I have never performed the behavior), $2=$ rarely, $3=$ sometimes, $4=$ always, and N/A = not applicable. Scoring system:

According to range of total scores, which lie between $(0-160)$, patient were classified as: positive behavior and negative behavior. Positive behavior if their total score was $\geq 50 \%$ and negative behavior if their total score was $<50 \%$.

Tool IV: - Nursing Teaching Program

This tool was developed by the researcher in simple Arabic language based on literature review, researcher experience, and opinion of the medical and nursing expertise to provide the patient with the necessary information and instructions about essential hypertension. It was applied by the researcher, it covered and consisted of the following:-

1) Definition and types of blood pressure?

2) Definition, risk factors, signs and symptoms, and complications of essential hypertension.

3) Life style modifications (weight loss, adoption of dietary approaches to stop hypertension diet, increase physical activity, reduce dietary salt intake, reducing stress, and smoking cessation).

4) Low blood pressure (definition, signs and symptoms, and how to manage these symptoms).

\subsection{Methods}

- An official permission was obtained from the head of medical department and outpatient clinics.

- Data was collected in the internal medicine department and outpatient clinics at Assiut University Hospital during the period from January 2017 to September 2017.

- The study tools and nursing teaching program were formulated after review of the literature.

- The content validity was done by 5 expertises in medical \& nursing field.

- Patient's agreement for voluntary participation was obtained after the purpose and nature of the study were explained.

- Data were assured confidentiality and anonymity and were collected using the pre-mentioned study tools.

- A Pilot study was conducted on 6 patients $(10 \%)$ to examine the feasibility of the study and clarity of the tools. Those patients who were involved in the pilot study were included in the main study.

- The researcher met with each patient individually, oral agreement for voluntary participation in the study was taken from the patients after the study, and its aims were explained.

- $\quad$ For both groups tool I, the researcher filled II and III.

- For the study group patients the researcher explained the nursing teaching program in 5 sessions, the duration of each session was about 30 minute, including 5 minutes for discussion and feedback.

\subsection{Program sessions}

- The researcher in the first session explained to the patient simplified data about definition, types, classifications, readings, risk factors and complications of essential hypertension.

- Second session included simplified instructions to help reduce blood pressure such as: weight reduction, healthy diet and salt reduction in diet.

- Third session: physical activity and exercise, and ways to reduce stress such as deep breathing exercise and meditation.

- Fourth session: instructions about smoking cessation, symptoms of high blood pressure that require going to hospital, and instructions regarding medication.

- Fifth session: information about the symptoms of warning signs for hypertensive patients, symptoms and causes of hypotension, and what must be done when feeling symptoms of hypotension.

- $\quad$ Each session ended by a summary of its content and feedback from the patients through discussion and asking questions, 
for the study group tool (II) used immediately to assess patient's knowledge, and each patient in the study group obtained a copy of the nursing teaching program booklet in simple Arabic language.

- Evaluation was carried out through introducing tool (II) and tool (III) for all the studied sample to distinguish between control and study group and between the initial assessment of the studied group and their assessment at the time of follow up 6 weeks after application of the nursing teaching program.

\section{Ethical considerations}

Research proposal was approved from ethical committee in the faculty of nursing, there was no risk for study subjects during application of the research, the study followed common ethical principles in clinical research, and oral consent was obtained from patients or guidance who were willing to participate in the study, after explaining the nature and purpose of the study, confidentiality and anonymity were assured, study subject had the right to refuse to participate and/or withdraw from the study without any rational at any time, and study subject privacy was considered during collection of data.

Table 1: Personal Characteristics of Patients in the Study and Control Group $(\mathrm{N}=60)$

\begin{tabular}{|c|c|c|c|c|c|c|}
\hline \multicolumn{2}{|c|}{ Items } & \multicolumn{2}{|c|}{$\begin{array}{l}\text { Control group }(\mathrm{n}=30) \\
\text { N. } \%\end{array}$} & \multicolumn{2}{|c|}{$\begin{array}{l}\text { Study group }(\mathrm{n}=30) \\
\text { N. \% }\end{array}$} & \multirow[t]{2}{*}{$\mathrm{P}$ value } \\
\hline 1) & Gender: & & & & & \\
\hline & Male & 10 & 33.3 & 5 & 16.7 & \multirow{3}{*}{$0.116 \mathrm{~ns}$} \\
\hline & Female & 20 & 66.7 & 25 & 83.3 & \\
\hline 2) & Age: & \multirow{2}{*}{\multicolumn{2}{|c|}{13.3}} & & & \\
\hline & $18-45$ & & & 4 & 13.3 & \multirow{4}{*}{$1.000 \mathrm{~ns}$} \\
\hline & $46-55$ & 11 & 36.7 & 12 & 40.0 & \\
\hline & $65-56$ & 15 & 50.0 & 14 & 46.7 & \\
\hline 3) & Marital status: & & & & & \\
\hline & Single & 1 & 3.3 & 2 & 6.7 & \multirow{5}{*}{$0.75 \mathrm{~ns}$} \\
\hline & Married & 26 & 86.7 & 24 & 80.0 & \\
\hline & Divorced & 0 & 0.0 & 0 & 0 & \\
\hline & Widowed & 3 & 10.0 & 4 & 13.3 & \\
\hline 4) & Level of education: & & & & & \\
\hline & University & 2 & 6.7 & 2 & 6.7 & \multirow{5}{*}{$0.216 \mathrm{~ns}$} \\
\hline & Secondary education & $\begin{array}{l}2 \\
6\end{array}$ & $\begin{array}{l}0.1 \\
20.0\end{array}$ & 1 & 3.3 & \\
\hline & Basic education & 4 & $\begin{array}{l}20.0 \\
13.3\end{array}$ & $\begin{array}{l}1 \\
5\end{array}$ & 16.7 & \\
\hline & Read and write & 0 & 00.0 & 2 & 6.7 & \\
\hline$\bullet$ & Illiterate & 18 & 60.0 & 20 & 66.7 & \\
\hline$?$ & Employee & 6 & 20.0 & 1 & 3.3 & \multirow{4}{*}{$0.133 \mathrm{~ns}$} \\
\hline & Unemployed & 2 & 6.7 & 3 & 10.0 & \\
\hline & Retired & 3 & 10.0 & 1 & 3.3 & \\
\hline - & House wife & 19 & 63.3 & 25 & 83.3 & \\
\hline
\end{tabular}

\section{Statistical design}

Data entry was done using compatible personal computer by investigator. The statistical analysis was done using SPSS- statistical software package Excel for figures. The content of each tool was analyzed, categorized and then coded by the investigator. Data were presented using descriptive statistics in the form of frequencies and percentages for qualitative variables, and means and standard deviations for quantitative variables. P-value considered statistically significant when $\mathrm{P}$ value $<0.05$.

\section{Results}

Table (1): This table reveals that, the majority $(83.3 \%)$ of the study group and about two thirds $(66.7 \%)$ of the control group were female. Regarding age half $(50 \%)$ of the control group and more than two fifths $(46.7 \%)$ of the study group their age range between 56 -
65 years old. Looking at marital status; the highest percentage in both groups were married $(86.7 \%$ and $80 \%)$ respectively. In addition it was found that the highest percentages in both groups were illiterate and house wives. There was no statistically significant difference between the study and control groups as regard socio-demographic characteristics.

Table (2): the above table mentions that, there was a statistically significant difference between the study and control group as regard hypertension definition, drug compliance and complications in post implementing the nursing teaching program.

Table (3): this table shows that, there was a statistically significant difference between the study and control group regarding hypertension self - management behaviors except self - integration in post implementing nursing teaching program.

Table (4): This table reported that, there was statistically a significant difference as regard total knowledge and self management behavior scores between the study and control group post implementing the nursing teaching program.

Table 2: Comparison between the Study and Control Group Regarding their Knowledge Pre and 6 Weeks Post Implementing the Nursing

\begin{tabular}{|c|c|c|c|c|c|c|c|c|c|c|c|}
\hline \multirow[t]{2}{*}{ Items } & & \multicolumn{2}{|c|}{$\begin{array}{l}\text { Pre } \\
\text { Control group }\end{array}$} & \multicolumn{2}{|c|}{ Study group } & \multirow[t]{2}{*}{$\mathrm{P}$ value } & \multicolumn{2}{|c|}{$\begin{array}{l}\text { Post } \\
\text { Control group }\end{array}$} & \multicolumn{2}{|c|}{ Study group } & \multirow[t]{2}{*}{$\mathrm{P}$ value } \\
\hline & Definition: & N. & $\%$ & $\mathrm{~N}$. & $\%$ & & N. & $\%$ & $\mathrm{~N}$. & $\%$ & \\
\hline$\bullet$ & Correct & 0 & 0.0 & 0 & 0.0 & & 0 & 0.0 & 11 & 36.6 & \\
\hline$\bullet$ & Incorrect & 2 & 6.7 & 3 & 10.0 & 1.000 & 2 & 6.7 & 2 & 6.7 & $0001 * *$ \\
\hline$\bullet$ & Don't know & 28 & 93.3 & 27 & 90.0 & ns & 28 & 93.3 & 17 & 56.7 & $.001 \cdots$ \\
\hline 2) & Medical management: & & & & & & & & & & \\
\hline$\bullet$ & Correct & 18 & 60.0 & 17 & 56.7 & & 19 & 63.4 & 16 & 53.4 & \\
\hline$\bullet$ & Incorrect & 10 & 33.3 & 10 & 33.3 & 0.490 & 10 & 33.3 & 13 & 43.3 & 0.159 \\
\hline$\bullet$ & Don't know & 2 & 6.7 & 3 & 10.0 & ns & 1 & 3.3 & 1 & 3.3 & \\
\hline
\end{tabular}




\begin{tabular}{|c|c|c|c|c|c|c|c|c|c|c|c|}
\hline 3) & Drug compliance: & & & & & & & & & & \multirow{4}{*}{$\begin{array}{l}0.000 \\
* * *\end{array}$} \\
\hline - & Correct & 11 & 36.6 & 12 & 40 & \multirow{3}{*}{$\begin{array}{l}0.648 \\
\text { ns }\end{array}$} & 12 & 40.0 & 1 & 3.3 & \\
\hline & Incorrect & 14 & 46.7 & 16 & 53.3 & & 15 & 50.0 & 28 & 93.4 & \\
\hline • & Don't know & 5 & 16.7 & 2 & 6.7 & & 3 & 10.0 & 1 & 3.3 & \\
\hline 4) & Lifestyle: & & & & & & & & & & \\
\hline$\bullet$ & Correct & 13 & 43.3 & 13 & 43.3 & & 13 & 43.3 & 17 & 56.7 & \\
\hline & Incorrect & 6 & 20.0 & 4 & 13.4 & 0.157 & 9 & 30.0 & 11 & 36.6 & 0.063 \\
\hline$\bullet$ & Don't know & 11 & 36.6 & 13 & 43.3 & ns & 8 & 26.7 & 2 & 6.7 & \\
\hline 5) & Diet: & & & & & & & & & & \\
\hline$\bullet$ & Correct & 13 & 43.3 & 14 & 46.7 & & 14 & 46.7 & 18 & 60.0 & \\
\hline & Incorrect & 14 & 46.7 & 13 & 43.3 & 0.851 & 13 & 43.3 & 12 & 40.0 & 0.091 \\
\hline • & Don't know & 3 & 10.0 & 3 & 10.0 & ns & 3 & 10.0 & 0 & 0.0 & \\
\hline 6) & Complications: & & & & & & & & & & \\
\hline • & Correct & 15 & 50.0 & 15 & 50.0 & & 17 & 56.7 & 28 & 93.4 & \\
\hline & Incorrect & 4 & 13.4 & 2 & 6.7 & 0.562 & 3 & 10.0 & 1 & 3.3 & $0007 * *$ \\
\hline • & Don't know & 11 & 36.6 & 13 & 43.3 & $\mathrm{~ns}$ & 10 & 33.3 & 1 & 3.3 & $0.00 / \cdots$ \\
\hline
\end{tabular}

Table 3: Comparison between the Study and Control Group Regarding their Hypertension Self - Management Behaviors Pre and 6 Weeks Post Implementing the Nursing Teaching Program $(\mathrm{N}=60)$

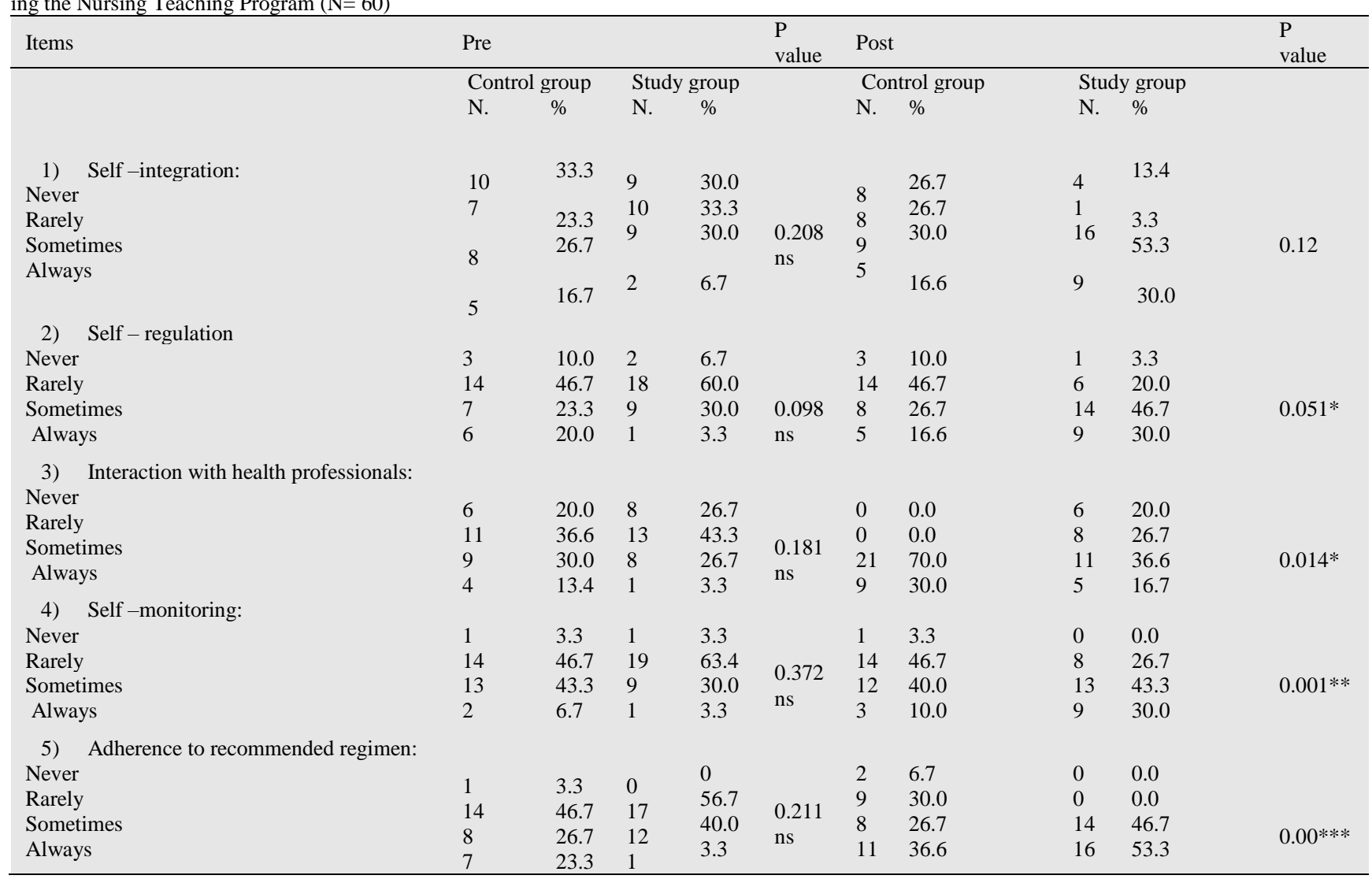

Table 4: Total Percentage of Patients, Knowledge and Self-Management Behaviors for Both Groups About Hypertension (N=6)

\begin{tabular}{|c|c|c|c|c|c|c|c|c|c|c|}
\hline \multirow[t]{2}{*}{ Variables } & \multicolumn{4}{|c|}{ Control sample $(n=30)$} & \multirow[t]{2}{*}{ P-value } & \multicolumn{4}{|c|}{ Study sample $(n=30)$} & \multirow[t]{2}{*}{ P-value } \\
\hline & Pre & & Post & & & Pre & & Post & & \\
\hline & N. & $\%$ & N. & $\%$ & & N. & $\%$ & N. & $\%$ & \\
\hline \multicolumn{11}{|l|}{ I- Patients' knowledge:- } \\
\hline Satisfactory & 15 & 50.0 & 19 & 63.3 & & 12 & 40.0 & 30 & 100.0 & \\
\hline Unsatisfactory & 15 & 50.0 & 11 & 36.7 & $0.13 \mathrm{~ns}$ & 18 & 60.0 & 0 & 0.0 & $0.00 * *$ \\
\hline Total & 30 & 100.0 & 30 & 100.0 & & 30 & 100.0 & 30 & 100.0 & \\
\hline \multicolumn{11}{|c|}{ II- Patients' self-management behavior:- } \\
\hline Positive behavior & 13 & 43.3 & 14 & 46.7 & & 13 & 43.3 & 30 & 100.0 & \\
\hline Negative behavior & 17 & 56.7 & 16 & 53.3 & $0.500 \mathrm{~ns}$ & 17 & 56.7 & 0 & 0.0 & $0.00 * *$ \\
\hline
\end{tabular}

\section{Discussion}

Essential hypertension is a major cause of cardiovascular morbidity (Clark et al., 2010). It is a predisposing risk factor for stroke, myocardial infarction, congestive heart failure, arterial aneurysm, and the leading cause of chronic renal failure. Approximately $90 \%$ to $95 \%$ of hypertension, affecting $>1$ billion adults worldwide, is the essential hypertension subtype (Wang et al., 2013).
The effective management of hypertension requires an individual to be knowledgeable about the disease, adhere to prescribed medications, and have the confidence to execute the behaviors necessary to manage the disease (Francois, 2015). Well-designed educational interventions with active participation of the patients are necessary for increasing HTN knowledge, self-monitoring, and control (Beigi et al., 2014).

In the present study, the incidence of female sex was more than male sex which is consistent with (Grant, 2013) who revealed that more than three quarters of the studied patients were female and 
also disagree with (Patil et al., 2015) who stated that more than half of the sample were male.

In this study, findings regarding age clarified that the incidence of hypertension was higher in age group $56-65$ years. This result is in line with (Sherlock et al., 2014) who reported that hypertension is most prevalent in patients 55- 64 years and also disagree with (Duboz et al., 2016) who reported that more than half of the participants were aged $<40$ years.

As regard marital status of the studied patients, the present study results revealed that most patient were married. In the same line (Eshah and Al-daken, 2015) found that the majority of the patients were married.

Concerning level of education and occupation; the current study showed that the majority of patient were illiterate and house wives. This results supported by (Awoke et al., 2012) who reported that most participants were house wives and without formal education. The present study mentioned that, there was a statistically significant difference between the study and control group after implementing the nursing teaching program as regard knowledge level of patients about hypertension. In the same line, (Jarelnape et al., 2016) reported that health education program was effective in improving patient's knowledge.

This study reported that, there was a statistically significant difference between the study and control group after implementing the nursing teaching program as regard self management behaviors about hypertension. This result agree with (Rujiwatthanakorn et al. 2011) who reported that self management program was effective in enhancing subjects' self-management regarding hypertension.

\section{Conclusion}

The results of the present study concluded that; there was a statistically significant difference in patients' knowledge and self management behaviors after implementing the nursing teaching program. Also, there was a significant relation between level of knowledge and self management behaviors.

\section{Recommendations}

For patients:-

- A continuous educational program should be planned and offered to patients on regular basis in medical department and outpatient clinics.

- Increase patients' awareness about the importance of follow up to avoid and prevent any complications through utilizing the mass media (radio and television) and health classes in different health agencies.

- Provide each patient with a written instruction booklet in simple Arabic language contains many colored pictures.

For nurses:-

Periodical assessment of nurses' knowledge and practice in relation to bundle of care of patients with hypertension. Also, nurses should always update themselves with current information regarding hypertension.

\section{References}

[1] Akhter, N (2010): Self-management among patients with hypertension in Bangladesh. Published Master Thesis. Prince of Songkla University.

[2] Alp, A ., Akdam, H ., Akar, H ., Koseoglu, K ., Ozkul, A ., Meteoglu ,I and Yenicerioglu, Y (2014): Polyarteritis nodosa complicated by posterior reversible encephalopathy syndrome: a case report. Nefrologia .34(6):789-96. DOI: https://doi.org/10.3265/Nefrologia.pre2014.Sep.12510

[3] Awoke, A., Awoke, T., Alemu, S and Megabiaw, B (2012): Prevalence and associated factors of hypertension among adults in Gondar, Northwest Ethiopia: a community based cross-sectional study. BMC Cardiovascular Disorders.12 (1):113. https://doi.org/10.1186/14712261-12-113.
[4] Babu, A.S and Grace, S.L (2015): Cardiac Rehabilitation for Hypertension Assessment and Control: Report From the International Council of Cardiovascular Prevention and Rehabilitation. The Journal of Clinical Hypertension. 17 (11): 831-836. https://doi.org/10.1111/jch.12663.

[5] ]Baushi, K (2015): Arterial Hypertension of Patients who Visited "Xh. Kongoli" Hospital in Elbasan during a Period of $2011-2014$. $\begin{array}{llllll}\text { Anglisticum } & \text { Journal } & .4 & \text { (4): } & 337-\end{array}$ DOI: http://dx.doi.org/10.0001/(aj).v4i4.1228

[6] Beigi, M.A.B., Zibaeenezhad, M.J., Aghasadeghi, K., Jokar, A., Shekarforoush, S and Khazraei, H (2014): The Effect of Educational Programs on Hypertension Management. International Cardiovascular Research Journal. 8 (3) 94- 98. PMCID: PMC4109043. PMID 25177671.

[7] Bell, K., Twiggs, J and Olin, B.R (2015): Hypertension: The Silent Killer Updated JNC -8 Guideline Recommendations. Alabama Pharmacy Association: Continuing Education.1-8.

[8] Bolívar, J.J (2013): Essential Hypertension: An Approach to Its Etiology and Neurogenic Pathophysiology. International Journal of Hypertension.1-11. https://doi.org/10.1155/2013/547809.

[9] Ciccone , C.D (2015) Pharmacology in Rehabilitation. Ch21.5th Ed. USA: F.A. Davis Company. Pp 316.

[10] Clark, C.E., Smith, L.F.P., Taylor, R.S and Campbell, J.L (2010): Nurse led interventions to improve control of blood pressure in people with hypertension: systematic review and meta-analysis. British Medical Journal.341: c3995. https://doi.org/10.1136/bmj.c3995.

[11] Conn, P.M (2013): Animal Models for the Study of Human Disease.Ch 8. First Ed. China: Elsevier Inc. Pp 183.

[12] Dalai, N., Cui, H., Yan, M., Rile, G., Li, S and Su, X (2014) Risk factors for the development of essential hypertension in a Mongolian population of China: a case- control study .Genetics and Molecular Research Journal. 13(2):3283-91.DOI:https://doi.org/10.4238/ 2014.April29.6.

[13] uboz, P., Boëtsch, G., Gueye, L and Macia, E (2016 Hypertension in the Ferlo (Northern Senegal): prevalence, awareness, treatment and control.Pan . African Medical Journal.25:177 https://doi.org/10.1038/jhh.2013.142.

[14] Erkoc, S.B., Isikli, B., Metintas, S and Kalyoncu, C (2012): Hypertension Knowledge-Level Scale (HK-LS): A Study on development, validity and reliability. International Journal of Environmental Research. Public Health. 9 1018- 1029. DOI: https://doi.org/ 10.3390/ijerph9031018

[15] Eshah, N.F and Al-daken, L.I (2015): Assessing Publics' Knowledge about Hypertension in a Community- Dwelling Sample. Journal of $\begin{array}{lll}\text { Cardiovascular } & \text { Nursing.0 } & (0):\end{array}$ https://doi.org/10.1097/JCN.0000000000000227.

[16] Flynn, S.J., Ameling, J.M., Hill-Briggs, F ., Wolff, J. L ., Bone, L.R., Levine, D.M., Roter, D.L., Lewis-Boyer, L., Fisher, A. R ., Purnell, L ., Ephraim, P. L., Barbers , J ., Fitzpatrick, S.L., Albert, M.C., Cooper, L.A., Fagan, P.J., Martin, D., Ramamurthi, H.C and Boulware, L. E (2013): Facilitators and barriers to hypertension self- management in urban African Americans: perspectives of patients and family members. Patient Preference and Adherence Journal. (7):741-749. https://doi.org/10.2147/PPA.

[17] Francois, C (2015): "Hypertension Knowledge, Medication Adherence, and Self-efficacy Skills among African Ameri can Males in New York City". Master thesis. Monroe College.

[18] Gallagher, R., Chenoweth, L and Stein-Parbury, J (2008): Self-management in older patients with chronic illness. International Journal of Nursing Practice.14 373-382. https://doi.org/10.1111/j.1440172X.2008.00709.x.

[19] Ghosh, R., Bhattacharya, M., Khan, G., Chakraborty, S., Bhattacharya, R., Maji, U.K., Jana, P and Sinha, A K (2013): Diagnosis of essential hypertension in humans by the determination of plasma renal cortexin using enzyme- linked immunosorbent assay. Clinical Laboratory Journal. 59 (5-6):475-81. PMID: 23865344.

[20] Grant, A.M (2013): "Hypertension knowledge, expectation of care, social support and adherence to prescribed medications of African Americans with hypertension framed by the Roy adaptation model. PHD thesis. The City University of New York.

[21] James, P.A., Oparil, S., Carter, B.L., Cushman, W.C. , DennisonHimmelfarb,C., Handler, J., Lackland, D. T., LeFevre, M.L, MacKenzie, T.D., Ogedegbe, O., Smith , S.C., Svetkey, L.P, Taler, S.J., Townsend, R.R., Wright , J.T., Narva, , A.S and Ortiz, E(2014): Evidence- Based Guideline for the Management of High Blood Pressure in Adults Report from the Panel Members Appointed to the Eighth Joint National Committee (JNC 8). Clinical Review \& Education. E1:E14. Doi: 10.1001/ jama.2013. 284427

[22] Jarelnape, A.A.A., Abdullah, N.T.M., Yousif, K.I and El- Rufai, E.A (2016): The Effect of Health Educational Program on Patients' 
Knowledge about Hypertension and Its' Management (In Sudan White Nile State). International Journal of Preventive Medicine Research. 2(4): 17-22.

[23] Lewis, S.L., Dirksen, S.R., McLean, M and Bucher, H.L (2014) Medical-surgical nursing: assessment and man agement of clinical problems.Ch 33 .9th edition. Canada: Mosby, an imprint of Elsevier Inc. Pp 277, 713.

[24] Li, D.Z., Zhou, Y., Yang, Y.N., Ma, Y.T., Li, X.M., Yu, J., Zhao, Y. Zhai, H and Lao, L (2014): Acupuncture for Es sential Hypertension: A Meta- Analysis of Randomized Sham-Controlled Clinical Trials. Hindawi Publishing Cor poration Evidence-Based Complementary and Alternative Medicine.1-7 http://dx.doi.org/10.1155/2014/279478

[25] Liao, X., Yang, Z., Peng, D., Dai, H., Lei, Y., Zhao, Q., Han, Y and Wang, W (2014): Research Article: Association of T174M polymorphism of angiotensinogen gene with essential hypertension: A metaanalysis. Genetics and Molecular Biology.37 (3):473-79. PMCID:PMC4171772. https://doi.org/10.1590/S141547572014000400001.

[26] Mangena, P., Saban, S., Hlabyago, K.E and Rayner, B (2016): An approach to the young hypertensive patient. The South African Medical Journal .106 (1): 36-38 https://doi.org/10.7196/SAMJ.2016.v106i1.10329..

[27] Mersal, F.A and Mersal, N.A (2015): Effect of Evidence Based Lifestyle Guidelines on Self-Efficacy of Patients with Hypertension. International Journal of Current Microbiology and Applied Sciences .4(3): 244-263

[28] O'Sullivan, S.B., Schmitz, T.J and Fulk, G (2014): Physical Rehabilitation. Ch13.6th Ed. Philadelphia: F.A. Davis Company Pp 533.

[29] Patil, V.N., Dabhade, S., Katare, S., Pandit, P. T and Ghongane, B.B (2015): A survey of knowledge and aware ness in patients of hypertension and survey of information that patients receive from physician for hypertension in a tertiary care hospital. World Journal of Pharmacy and Pharmaceutical Sciences.4 (12): 980-991.

[30] Rimoldi, S.F., Scherrer, U and Messerli, F.H (2013): Secondary arterial hypertension: when, who, and how to screen? European Heart Journal.1 - 12. https://doi.org/10.1093/eurheartj/eht534.

[31] Rujiwatthanakorn, D., Panpakdee, O., Malathum, $\mathrm{P}$ and Tanomsup, S (2011): Effectiveness of a Self-Management Program for Thais with Essential Hypertension. Pacific Rim international journal of nursing research.15 (2):97- 110. Available at: https://tcithaijo.org/index.php/ PRIJNR/article/view/6518

[32] Sherlock, P.L., Beard, J., Minicuci, N., Ebrahim, S and Chatterji, S (2014): Cardiovascular disease: Hypertension among older adults in low and middle-income countries: prevalence, awareness and control International Journal of Epidemiology .43:116-28. https://doi.org/10.1093/ije/dyt215.

[33] Wang, J., Xiong, X and Liu, W (2013): Yoga for Essential Hypertension: A Systematic Review. PLOS ONE Journal.8 (10): e76357. https://doi.org/10.1371/journal.pone.0076357.

[34] Wikipedia (2016): Cardiovascular disease. Available at: https://en.wikipedia.org/wiki/Cardiovascular_disease\# cite_noteWHO2011-1.

[35] World Health Organization (2016): Cardiovascular diseases. Fact sheets. Available at http://www.who.int/mediacentre/factsheets/fs317/en/ 